\title{
CT Chest Findings in 100 Patients with COVID-19 Pneumonia in Egypt
}

\author{
NEVEEN SEIF AL-ISLAM SHAKER, M.D. and ALY ALY ALBARBARY, M.D. \\ The Department of Radio-Diagnosis, Faculty of Medicine, Tanta University
}

\begin{abstract}
Background: Coronavirus disease 2019 (COVID-19) cases are represented by variable spectrum of CT chest findings despite their clinical symptoms.

Aim of Study: Is to detect the CT findings despite different clinical presentation and standardize the COVID-19 lung assessment by non-enhanced chest CT.

Material and Methods: This was a descriptive study done at Radio-diagnosis Department at Tanta University. Patient underwent chest CT scan. The diagnoses of the cases was initially based on the criteria published by WHO on January 20202. Two radiologists reviewed the CT findings.
\end{abstract}

100 patients underwent chest CT scans March 29,2020 and September 30th, 2020, were descriptive enrolled. The cohort included $50(50 \%)$ men and $50(50 \%)$ women with a mean age of $46.29 \pm 13.21$. The symptomatic patients were 62 $(62 \%) \&$ the asymptomatic were $38(38 \%)$. The symptoms include fever, cough, ageusia $\&$ anosmia, the most predominant complaint were ageusia \& anosmia as 45 patients (79) suffered from. The asymptomatic cases were in close contact with proved COVID patients or had suspicious laboratory findings

Results: All cases underwent CT study five cases (\%\%) were normal, 35 (35\%) show consolidation, 89 (89\%) show ground glass opacification, 35 (35\%) with combined consolidation \& ground glass opacification. 5 cases show other nonspecific findings. 72 cases show bilateral consolidation while only 17 cases with unilateral distribution.

Conclusion: Pneumonia in COVID-19 cases usually manifests as bilateral, subpleural, ground-glass opacities with air bronchograms with ill-defined margins on chest CT. Even in asymptomatic cases, abnormal findings of chest CT may occur.

Key Words: COVID - CT chest - Ground glass opacification - Consolidation.

\section{Introduction}

STARTING from the end of 2019 in Wuhan, in the Hubei province of China, unknown etiology pneumonias was reported [1]. Chinese facilities has identified a new coronavirus, severe acute

Correspondence to: Dr. Neveen Seif Al-Islam Shaker, The Department of Radio-Diagnosis, Faculty of Medicine, Tanta University respiratory syndrome coronavirus 2 (SARS-CoV2; previously known as 2019-nCoV) as a causative microorganism on January 7 th, 2020 [2,3] . On January 30 th, 2020, a global health emergency was declared by WHO [4]. On February 18 th, 2020, the virus transmitted extensively from humans to humans resulting in more than 73,000 cases in 26 countries with mortality in 1875 cases [5,6] .

COVID-19 is definitively diagnosed using a reverse transcriptase-polymerase chain reaction (RT-PCR) assay, but its clinical sensitivity varies from $42 \%$ to $83 \%$ based on the duration of symptom length, viral load and quality of sample [7].

There are increasing reports of cases, typically COVID-19 by clinical manifestations and radiologically, who had positive RT-PCR assay after negative results [8].

Consequently, the importance of chest computed tomography (CT) in COVID-19 is continuously emerging with moderate evidence but significant differences of opinion about when and how to use CT for clinical workup or decisions in treatment. The American College of Radiology didn't prefer the usage of CT in patient's initial work [9] although the 7 th Chinese Novel Coronavirus Pneumonia Diagnosis and Treatment Strategy introduces CT imaging into the parameters clinically describing COVID-19 [10].

$\begin{array}{ll}\text { Abbreviation: } \\ \text { RT-PCR } & \text { : Reverse transcriptase-polymerase chain reaction. } \\ \text { CT } & \text { : Computed tomography. } \\ \text { Fig. } & \text { : Figure. } \\ \text { RSNA } & \text { : Radiological society of north of America. } \\ \text { NVvR } & \text { : Nederlandse Vereniging voor Radiologie. } \\ \text { Lung-RADS : Lung Reporting and Data System. } \\ \text { PI-RADS } & : \text { Prostate imaging Reporting and Data System. } \\ \text { BI-RADS } & : \text { Breast imaging Reporting and Data System. } \\ \text { CO-RADS } & : \text { COVID-19 Reporting and Data System. } \\ \text { WHO } & \text { : World health organization. } \\ \text { PACS } & : \text { Picture archiving and communication systems. }\end{array}$


If symptoms escalate or in a resourceconstrained for RT-PCR situation, recently statement of the Fleischner Society states that imaging, especially, CT scanning, had an important role [11]

CT results of COVID-19 are partly overlapped with many disorders, primarily infections of viral origin, but also reveal characteristics less commonly seen in other situations [12]. There were many efforts done for standardization of CT reports for cases with suspicion of COVID-19. For example, the RSNA expert consensus statement [13] on reporting recently proposes uniform nomenclature and a classification for COVID-19 pneumonia in four categories (i.e. typical appearance, indeterminate appearance, atypical appearance, and negative for pneumonia).

In March 2020, the Dutch Radiological Society (Nederlandse Vereniging voor Radiologie, NVvR) initiated a COVID-19 network to facilitate development and nationwide dissemination of COVID19-related information and tools. Within this network, a "COVID-19 standardized reporting" working group was formed. The authors developed a standardized assessment scheme for pulmonary involvement of COVID-19 to be able to compare data across institutions and populations and, thus, provide a basis for gathering scientific evidence and improved communication with referring physicians. Because the system is based on other efforts for standardization, such as Lung-RADS, PI-RADS or BI-RADS, the authors chose the acronym CORADS, for COVID-19 Reporting and Data System [14]. The system was iteratively refined through feedback from members and input from clinical partners. This type of system has been shown to work well in clinical practice and to allow for selection of optimal cutoff points for various clinical decisions depending on the tasks at hand. The current version represents the consensus formed on April 7th, 2020 [15].

$\mathrm{CT}$ has a big role in diagnosing and treating lung diseases. In our knowledge, COVID-19 pneumonia's characteristics are varied from normal view to diffuse lung shifts. Also, many radiological variations are found at different points during the course of COVID-19. Our study was aiming to demonstrate chest $\mathrm{CT}$ features evolution in cases of pneumonia due to COVID-19 [16]

\section{Patients and Methods}

This was a descriptive study done at a Radiodiagnosis Departments at Tanta University. Patients underwent chest CT scan. Two radiologists reviewed the CT findings.
This study includes 100 patients (50 female and 50 male), with mean age was $46.29 \pm 13$, were referred to CT Unit of Radiodiagnosis Department of University Hospitals, for CT evaluation of the chest. This study took one year of duration started from March 2020 - September 2020, this study done after informed consents obtained from all patients and ethical committee approval was obtained. The privacy of participants and confidentiality of data were guaranteed during the study. The results were used as scientific material only and were not used by any legal authorities.

The symptomatic patients were $62(62 \%) \&$ the asymptomatic ones were 38 (38\%) (Table 1). The symptoms include fever, cough, ageusia \& anosmia, the most predominant complaints were ageusia $\&$ anosmia as 45 patients $(79 \%)$ suffered from (Table 2).

\section{Patients population:}

\section{Inclusion criteria:}

- Patients suspected or proved with COVID or their contact family members.

- Both sexes are included.

- Adult age groups.

\section{Exclusion criteria:}

- Children (no many cases or enough studies performed on children with COVID).

- Cases with known previous underlying lung disease (not to mistaken the CT chest findings of COVID with the underlying lung changes).

History taking: All patients were questioned in detail for previous travelling, chest manifestations; duration and onset. Documentation of all collected data were done.

All cases were underwent clinical assessment and laboratory investigation. The asymptomatic patients admitted to CT chest had an abnormal laboratory findings. Some cases did naso pharyngeal swap mainly the asymptomatic patients with suspected CT findings who have suspicious history of travelling to pandemic areas of in contact to COVID positive patients.

\section{CT imaging technique:}

CT image acquisition: In the supine position, all CT scanning was done. Scans were done from the level of the upper thoracic inlet to the inferior level of the costophrenic angle Images were reconstructed with a slice thickness of $1.5 \mathrm{~mm}$ or $1 \mathrm{~mm}$ and an interval of $1.5 \mathrm{~mm}$ or $1 \mathrm{~mm}$, respectively. The reconstructed images were transmitted to the workstation and picture archiving and communi- 
cation systems (PACS) for multiplanar reconstruction post-processing. After separate evaluations, any disagreements were resolved by discussion and consensus. CT imaging features recorded from our cohort are summarized. Decisions were reached by consensus.

Evaluation chest CT scan was done in each case by for the next features: (a) Ground-glass opacities presence; (b) Consolidation presence; (c) Ground glass opacities and consolidation literalities; (d) Other findings presence. Consolidation was defined as opacification with obscuration of margins of vessels and airway walls, whereas groundglass opacity was defined as hazy increased lung attenuation with vascular and bronchial margins preservation [17]. Then cases were evaluated by CORADS score.

\section{Statistical analysis:}

Analysis of data was conducted by SPSS v22 (IBM, Armonk, NY: IBM Corp). KolmogorovSmirnov test was used for verification of normality of distribution of data. Categorical variables were compared by Chi-square, Fisher or Monte Carlo tests. Normal-distribution quantitative variables were compared by Student $t$-test between both groups. The level of significance was judged at $5 \%$.

\section{Results}

All cases underwent CT study five cases (5\%) were normal, 35 (35\%) showed consolidation (Fig. 1), $89(89 \%)$ show ground glass opacification (Fig. 2), $35(35 \%)$ with combined consolidation \& ground glass opacification (Fig. 3). 5 cases show other nonspecific findings (Fig. 4). 72 cases show bilateral consolidation \& only 17 cases with unilateral distribution (Table 3 ).

Table (1): Distribution of the studied cases according to Asymptomatic $(\mathrm{n}=100)$.

\begin{tabular}{cc}
\hline Asymptomatic & No. of cases $(\%)$ \\
\hline No & $62(62 \%)$ \\
Yes & $38(38 \%)$ \\
\hline
\end{tabular}

Table (2): Distribution of the studied cases according to complaint $(n=62)$ in symptomatic cases.

\begin{tabular}{cc}
\hline Symptoms & No. of cases $(\%)$ \\
\hline Fever: & $25(40.3 \%)$ \\
No & $37(59.7 \%)$ \\
Yes & \\
Cough: & $24(38.7 \%)$ \\
No & $38(61.3 \%)$ \\
Yes & \\
Ageusia \& anosmia: & $13(21 \%)$ \\
No & $49(79 \%)$ \\
Yes
\end{tabular}

Table (3): Comparison between the two studied groups according to different parameters.

\begin{tabular}{|c|c|c|c|c|c|}
\hline \multirow{2}{*}{ Symptoms } & \multirow{2}{*}{$\begin{array}{c}\text { Total } \\
(\mathrm{n}=100)\end{array}$} & \multicolumn{2}{|c|}{ Asymptomatic } & \multirow{2}{*}{$\begin{array}{l}\text { Test } \\
\text { of sig. }\end{array}$} & \multirow{2}{*}{$p$} \\
\hline & & No $(n=62)$ & Yes $(n=38)$ & & \\
\hline $\begin{array}{l}\text { Sex: } \\
\text { Male } \\
\text { Female }\end{array}$ & $\begin{array}{l}50(50 \%) \\
50(50 \%)\end{array}$ & $\begin{array}{l}30(48.4) \\
32(51.6)\end{array}$ & $\begin{array}{l}20(52.6) \\
18(47.4)\end{array}$ & $\chi^{2}=0.170$ & 0.680 \\
\hline $\begin{array}{l}C T \text { findings: } \\
\text { No } \\
\text { Yes }\end{array}$ & $\begin{array}{l}95(95 \%) \\
5(5 \%)\end{array}$ & $\begin{array}{l}62(100 \%) \\
0(0 \%)\end{array}$ & $\begin{array}{l}33(86.8 \%) \\
5(13.2 \%)\end{array}$ & $\chi^{2}=8.587 *$ & $\mathrm{FE} p=0.007^{*}$ \\
\hline $\begin{array}{l}\text { Consolidation: } \\
\text { No } \\
\text { Yes }\end{array}$ & $\begin{array}{l}65(65 \%) \\
35(35 \%)\end{array}$ & $\begin{array}{l}30(48.4 \%) \\
32(51.6 \%)\end{array}$ & $\begin{array}{l}35(92.1 \%) \\
3(7.9 \%)\end{array}$ & $\chi^{2}=19.793 *$ & $<0.001 *$ \\
\hline $\begin{array}{l}\text { Ground glass: } \\
\text { No } \\
\text { Yes }\end{array}$ & $\begin{array}{l}11(11 \%) \\
89(89 \%)\end{array}$ & $\begin{array}{l}0(0 \%) \\
62(100 \%)\end{array}$ & $\begin{array}{l}11(28.9 \%) \\
27(71.1 \%)\end{array}$ & $\chi^{2}=20.166^{*}$ & $\mathrm{FE}_{p}<0.001 *$ \\
\hline $\begin{array}{l}\text { Combined consolidation \& GG other: } \\
\text { No } \\
\text { Yes }\end{array}$ & $\begin{array}{l}35(35 \%) \\
96(96 \%) \\
4(4 \%)\end{array}$ & $\begin{array}{l}32(51.6 \%) \\
62(100 \%) \\
0(0 \%)\end{array}$ & $\begin{array}{l}3(7.9 \%) \\
34(89.5 \%) \\
4(10.5 \%)\end{array}$ & $\begin{array}{l}\chi^{2}=19.793^{*} \\
\chi^{2}=6.798^{*}\end{array}$ & $\begin{array}{l}<0.001 * \\
\mathrm{FE}_{p=0.019 *}\end{array}$ \\
\hline $\begin{array}{l}\text { Ground glass unilateral: } \\
\text { No } \\
\text { Yes }\end{array}$ & $\begin{array}{l}83(83 \%) \\
17(17 \%)\end{array}$ & $\begin{array}{l}56(90.3 \%) \\
6(9.7 \%)\end{array}$ & $\begin{array}{l}27(71.1 \%) \\
11(28.9 \%)\end{array}$ & $\chi^{2}=6.200 *$ & $0.013^{*}$ \\
\hline $\begin{array}{l}\text { Bilateral: } \\
\text { No } \\
\text { Yes }\end{array}$ & $\begin{array}{l}28(28 \%) \\
72(72 \%)\end{array}$ & $\begin{array}{l}6(9.7 \%) \\
56(90.3 \%)\end{array}$ & $\begin{array}{l}22(57.9 \%) \\
16(42.1 \%)\end{array}$ & $\chi^{2}=27.170^{*}$ & $<0.001 *$ \\
\hline $\begin{array}{c}\text { Score: } \\
1 \\
2 \\
3 \\
4 \\
5\end{array}$ & $\begin{array}{l}5(5 \%) \\
5(5 \%) \\
18(18 \%) \\
37(37 \%) \\
35(35 \%)\end{array}$ & $\begin{array}{l}0(0 \%) \\
0(0 \%) \\
6(9.7 \%) \\
24(38.7 \%) \\
32(51.6 \%)\end{array}$ & $\begin{array}{l}5(13.2 \%) \\
5(13.2 \%) \\
12(31.6 \%) \\
13(34.2 \%) \\
3(7.9 \%)\end{array}$ & $\chi^{2}=36.352$ & $<0.001 *$ \\
\hline $\begin{array}{l}\text { Min. - Max. } \\
\text { Mean } \pm \text { SD. } \\
\text { Median (IQR) }\end{array}$ & $\begin{array}{l}1.0-5.0 \\
3.92 \pm 1.09 \\
4.0(3.0-5.0)\end{array}$ & $\begin{array}{l}3.0-5.0 \\
4.42 \pm 0.67 \\
5.0(4.0-5.0)\end{array}$ & $\begin{array}{l}1.0-5.0 \\
3.11 \pm 1.16 \\
3.0(2.0-4.0)\end{array}$ & $t=6.380^{*}$ & $<0.001 *$ \\
\hline
\end{tabular}




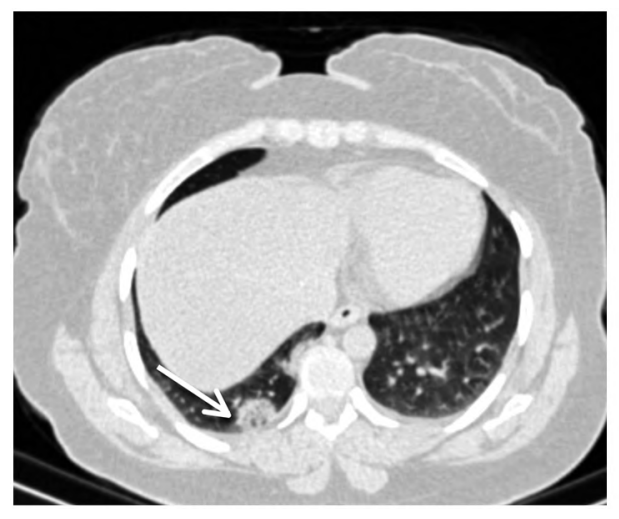

Fig. (1): Male COVID patient aged 36 years old presented with fever and cough. CT chest shows area of consolidation in the posterior segment of right lower lung lobe.

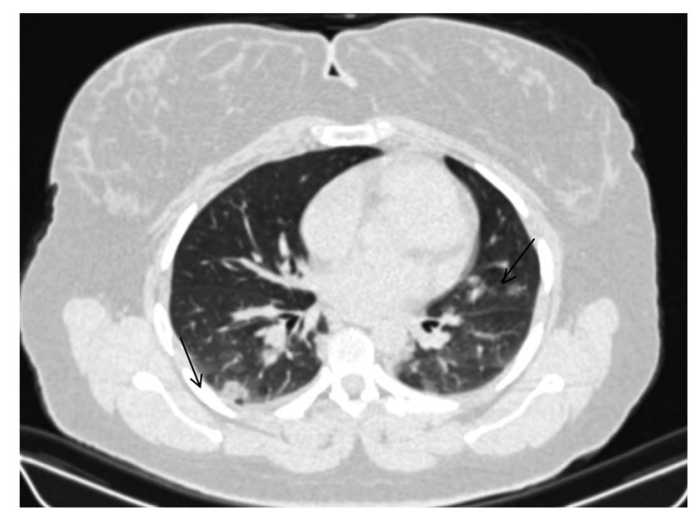

Fig. (3): Female COVID patient aged 40 years old presented with fever and cough axial and sagittal CT scan shows areas of consolidation and ground glass opacification scattered in both lung fields, peripherally located.

\section{Discussion}

The Coronaviridae virus family contains six types which are previously identified as coronaviruses infecting humans. They are enveloped, nonsegmented, positive-sense RNA viruses commonly spread in humans and other mammals [18]. Epidemics are due to two beta-coronaviruses, SARSCoV in 200214m [19,20] and MERS-CoV in 2012 [21] and the other four coronaviruses result in mild respiratory manifestations only which look like common cold. SARS-CoV-2 is the novel 7 th member in family of coronaviridae infecting the human being. SARS or MERS coronavirus diseases had a lower mortality rate than COVID-19 but SARS$\mathrm{CoV}-2$ is highly contagious causing a significant threat to health [16].

In this study, gender predilection wasn't found. This was in agreement with Xiaoyu Han [16] who got 42 men and 39 women among 81 patients,

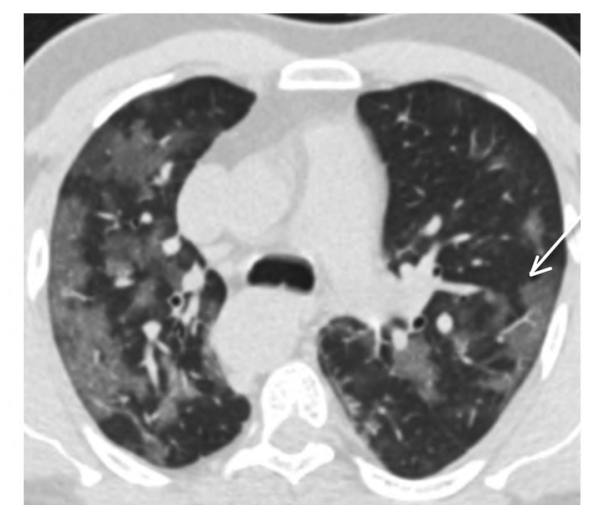

Fig. (2): Male COVID patient aged 70 years old presented with fever, cough, anosmia and agosia CT chest shows multiple bilateral predominant peripheral located ground glass opacification more on the right side.

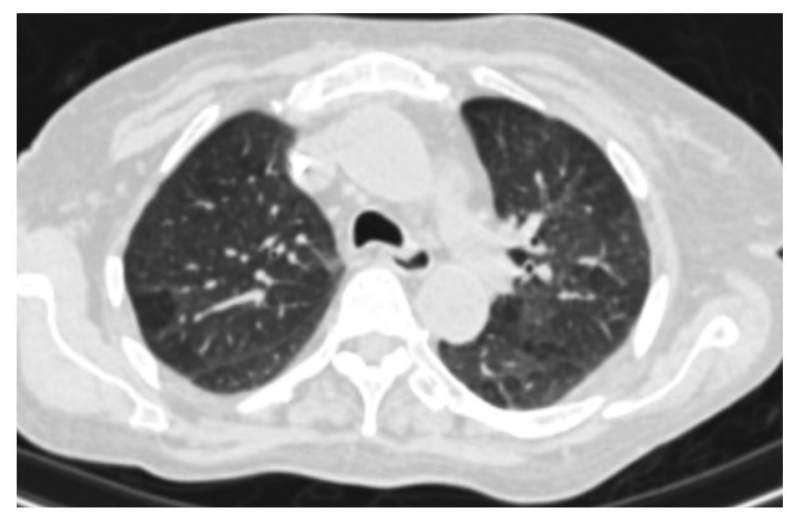

Fig. (4): Female COVID patient aged 70 years old with dyspnea, cough, fever, anosmia \& agosia CT chest shows mosaic appearance of both lung lobes.

However, Na Z, [22] showed that $73 \%$ of $41 \mathrm{COV}$ ID-19 cases were males.

This difference may be contributed to small sample size and variability in demographic characteristics.

In COVID-19 pneumonia cases, the most common manifestations were fever, cough, dyspnea, ageusia and anosmia. In 2-9\% of cases, non-specific manifestations occurred including vomiting, diarrhea, headache, dizziness, and generalized weakness. Fifteen asymptomatic cases were suspected by $\mathrm{CT}$ abnormal pulmonary features, proved later on by laboratory investigation, indicating that serum antibody testing and chest CT scans could be performed in asymptomatic high-risk persons with exposure history for COVID-19 pneumonia cases to enable early disease detection [23]. As we detected in current study most common complaints were fever, cough, ageusia \& anosmia and 27 cases 
were asymptomatic \& shows CT findings variable between ground glass opacification \& consolidation.

Bilateral lung involvement, with mainly peripheral subpleural with diffuse distribution lesions were found in the majority of cases. The groundglass opacity, with ill-defined margins was the main pattern. All previous features are non-specific and mimic many viruses [23]

Round cystic changes, lymphadenopathy, and pleural effusion on CT were not common in our cases in contrast to [24] who show these findings in their patients and suspect pleural effusion presence in COVID cases indicate poor prognostic indicator.

\section{Conclusions}

Pneumonia in COVID-19 cases usually manifests as bilateral, subpleural, ground-glass opacities with air bronchograms with ill-defined margins on chest CT. Even in asymptomatic cases, abnormal findings of chest CT may occur.

\section{Declarations:}

\section{1- Ethics approval and consent to participate:} Informed written consent was obtained from the participant, Ethical Committee of Faculty of Medicine of Tanta University Hospital approved the study.

2- Consent for publication: All patients provided written consent for data publishing. Authors approved the manuscript.

3- Availability of data and material: The authors verify that all data supporting the finding of the research are available within the manuscript and the raw data are available at the corresponding author on request.

4- Funding: Nil.

5-Acknowledgement: Nil.

\section{References}

1- WHO 2020: Novel coronavirus-China.,https://www.who int/csr/don/12-january-2020-novel-coronavirus-china/en/ (accessed Feb 12, 2020).

2- WHO 2020: Coronavirus disease (COVID-19) outbreak., https://www.who.int/emergencies/diseases/novelcoronavirus-2019; accessed February 15 th , 2020.

3- XU X., CHEN P., WANG J., et al.: Evolution of the novel coronavirus from the ongoing Wuhan outbreak and modeling of its spike protein for risk of human transmission. Sci. China Life Sci., 63 (3): 457-460, 2020.

4- MAHASE E.: China coronavirus: WHO declares international emergency as death toll exceeds 200. BMJ (368): m408, 2020.
5- CHAN J.F., YUAN S., KOK K.H., et al.: A familial cluster of pneumonia associated with the 2019 novel coronavirus indicating person-to-person transmission: A study of a family cluster. Lancet, (10223): 514-523, 2020.

6- HUANG C., WANG Y., LI X., et al.: Clinical features of patients infected with 2019 novel coronavirus in Wuhan, China. Lancet, (10223): 497-506, 2020.

7- AI T., YANG Z., HOU H., et al.: Correlation of Chest CT and RT-PCR Testing in Coronavirus Disease 2019 (COVID-19) in China: A Report of 1014 Cases. Radiology, 200642, 2020.

8- FANG Y., ZHANG H., XIE J., et al.: Sensitivity of Chest CT for COVID-19: Comparison to RTPCR. Radiology, 20043, 2020.

9- HOPE M.D., RAPTIS C.A., SHAH A., HAMMER M.M and HENRY T.S.: A role for CT in COVID-19? What data really tell us so far, The Lancet, (10231): 1189-1190, 2020.

10- National Health Commission \& National Administration of Traditional Chinese Medicine: Diagnosis and Treatment Protocol for Novel Coronavirus Pneumonia (Trial Version 7). Chinese medical journal, 133 (9): 1087-1095.

11- RUBIN G.D., RYERSON C.J., HARAMATI L.B., et al.: The Role of Chest Imaging in Patient Management during the COVID-19 Pandemic: A Multinational Consensus Statement from the Fleischner Society, Radiology. Radiological Society of North America, 201365, 2020.

12- BAI H.X., HSIEH B., XIONG Z., et al.: Performance of radiologists in differentiating COVID-19 from viral pneumonia on chest CT, Radiology, 200823, 2020.

13- SIMPSON S., KAY F.U., ABBARA S., et al.: Radiological Society of North America Expert Consensus Statement on Reporting Chest CT Findings Related to COVID-19. Endorsed by the Society of Thoracic Radiology, the American College of Radiology, and RSNA, Radiol Cardiothorac Imaging, (2): e200152, 2020.

14- AN J.Y., UNSDORFER K.M.L. and WEINREB J.C.: BIRADS, C-RADS, CAD-RADS, LI-RADS, Lung-RADS, NI-RADS, O-RADS, PI-RADS, TI-RADS: Reporting and Data Systems. RadioGraphics, 39 (5): 1435-1436, 2019.

15- PROKOP M., EVERDINGEN W.V., REES T.V., et al.: CO-RADS - A categorical CT assessment scheme for patients with suspected COVID-19: definition and evaluation, radiology, 2019.

16- HAN X., JIANG N., CAO Y., ALWALID O., et al.: Radiological findings from 81 patients with COVID-19 pneumonia in Wuhan, China: A descriptive study Lancet Infect Dis., 20: 425-340, 2020.

17- JIN GU, YANQING FAN $\dagger$ and CHUANSHENG ZHENG Radiological findings from 81 patients with COVID-19 pneumonia in Wuhan, China: A descriptive study Lancet Infect Dis., 20: 425-340, 2020.

18- HANSELL D.M., BANKIER A.A., MacMAHON H., McLOUD T.C., MÜLLER N.L. and REMY J. FLEISCHNER: Society: Glossary of terms for thoracic imaging. Radiology, 246 (3): 697-722, 2008.

19- RICHMAN D.D., WHITLEY R.J., HAYDEN F.G., eds.: Clinical virology, 4th edn. Washington: ASM Press, 2016. 
20- KSIAZEK T.G., ERDMAN D., GOLDSMITH C.S., et al.: A novel coronavirus associated with severe acute respiratory syndrome. N. Engl. J. Med., 348: 1953-66, 2003.

21- KUIKEN T., FOUCHIER R.A.M., SCHUTTEN M., et al.: Newly discovered coronavirus as the primary cause of severe acute respiratory syndrome. Lancet, 362: 26370, 2003.

22- ZAKI A.M., VAN BOHEEMEN S., BESTEBROER T.M., OSTERHAUS A.D. and FOUCHIER R.A.: Isolation of a novel coronavirus from a man with pneumonia in Saudi Arabia. N. Engl. J. Med., 367: 1814-20, 2012.
23- NA Z., DING Z., WEN W., et al.: Clinical features of patients infected with 2019 novel coronavirus in Wuhan, China. Lancet, 395: 497-605, 2020.

24- AJLAN A.M., AHYAD R.A., JAMJOOM L.G., ALHARTHY A., MADANI T.A.: Middle East respiratory syndrome coronavirus (MERS-CoV) infection: Chest CT findings. AJR Am. J. Roentgenol., 203: 782-87, 2014.

25- NA Z., DING Z., WEN W., et al.: Clinical features of patients infected with 2019 novel coronavirus in Wuhan, China. Lancet, 395: 497-605, 2020.

\section{نتائج التصوير المقطعى الهحوسب للصدار في الهو 100 مريض

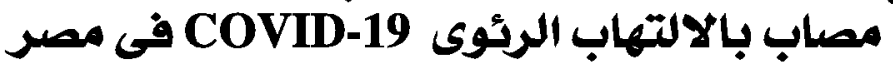

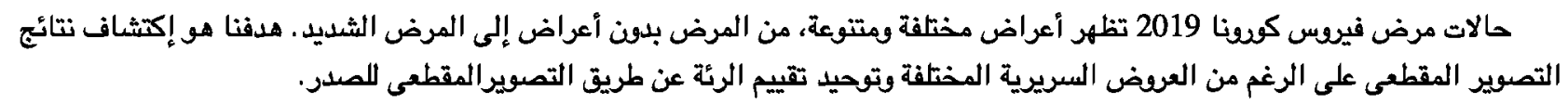

النتائج: خضع 100 مريض لفحص الصدر بالأشعة المقطعية فى 29 مارس 2020 و 30 سبتمبر 2020، وتم تسجيلهم وصفياً. ضمت

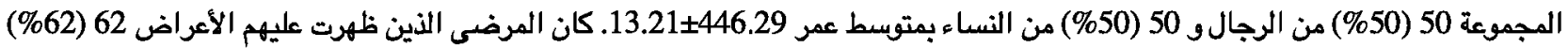

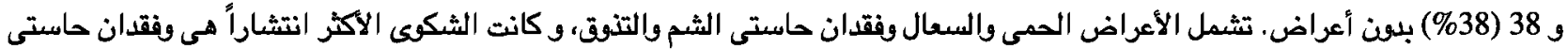

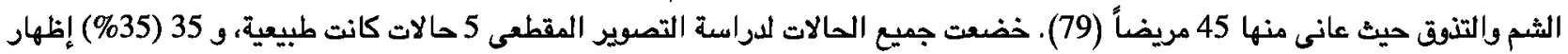

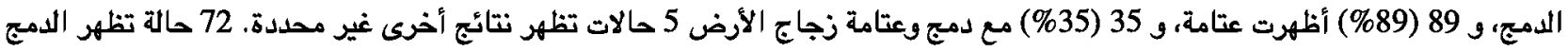
الثنائى بينما 17 حالة فقط مع التوالونيع أحادى الجانب.

الخلاصهة: يظهر الالتهاب الرئوى لـ كوفيد 19 فى حالات عادة على شكل عتامات ثثائية وتصت الجافية وزجاج أرضى مع تخطيطات القصبات الهوائية مع هوامش غير محددة في التصوير المقطعى للصدر. حتى فى الحالات التى لا تظهر فيها أعراض، قد تحدث نتائج غير طبيعية للتصوير المقطعى للمدر. 